\title{
Microsatellite-based genotyping of MHC class II DRB1 gene in Iberian and Alpine ibex
}

\author{
Alasaad, Samer ; Biebach, Iris ; Grossen, Christine ; Soriguer, Ramon C ; Perez, Jesus M ; Keller,
} Lukas F

\begin{abstract}
In an analysis of a microsatellite locus (OLADRB1) linked to the MHC DRB1 gene of Iberian and Alpine ibex (Capra pyrenaica and Carpa ibex), we detected strong linkage disequilibrium between both loci. The allele length polymorphism at OLADRB1 was unambiguously linked to a particular DRB1 allele. This allowed us to develop a DRB-STR matching method for both ibex species. Validation of the DRB-STR matching method was performed in 160 Iberian ibex from Spain and 98 Alpine ibex from Switzerland and Italy. This simple and relatively inexpensive protocol may find wide applications in a variety of research areas (e.g., mate choice, pathogen-driven selection) and in the biological conservation and management of the Western European ibex populations.
\end{abstract}

DOI: https://doi.org/10.1007/s10344-011-0592-0

Posted at the Zurich Open Repository and Archive, University of Zurich

ZORA URL: https://doi.org/10.5167/uzh-68826

Journal Article

Published Version

Originally published at:

Alasaad, Samer; Biebach, Iris; Grossen, Christine; Soriguer, Ramon C; Perez, Jesus M; Keller, Lukas F (2012). Microsatellite-based genotyping of MHC class II DRB1 gene in Iberian and Alpine ibex. European Journal of Wildlife Research, 58(4):743-748.

DOI: https://doi.org/10.1007/s10344-011-0592-0 


\title{
Microsatellite-based genotyping of MHC class II DRB1 gene in Iberian and Alpine ibex
}

\author{
Samer Alasaad • Iris Biebach • Christine Grossen • \\ Ramón C. Soriguer • Jesús M. Pérez • Lukas F. Keller
}

Received: 23 March 2011 /Revised: 25 October 2011 / Accepted: 27 October 2011 /Published online: 11 November 2011

(C) Springer-Verlag 2011

\begin{abstract}
In an analysis of a microsatellite locus (OLADRB1) linked to the MHC DRB1 gene of Iberian and Alpine ibex (Capra pyrenaica and Capra ibex), we detected strong linkage disequilibrium between both loci. The allele length polymorphism at OLADRB1 was unambiguously linked to a particular DRB1 allele. This allowed us to develop a DRBSTR matching method for both ibex species. Validation of the DRB-STR matching method was performed in 160 Iberian ibex from Spain and 98 Alpine ibex from Switzerland and Italy. This simple and relatively inexpensive protocol may find wide applications in a variety of research areas (e.g., mate choice, pathogen-driven selection) and in the biological
\end{abstract}

Communicated by C. Gortázar

S. Alasaad - I. Biebach • C. Grossen • L. F. Keller Institute of Evolutionary Biology and Environmental Studies (IEU), University of Zürich,

Winterthurerstrasse 190,

8057 Zurich, Switzerland

L. F. Keller

e-mail: lukas.keller@ieu.uzh.ch

C. Grossen

Department of Ecology and Evolution,

University of Lausanne,

CH-1015 Lausanne, Switzerland

S. Alasaad $(\bowtie) \cdot$ R. C. Soriguer

Estación Biológica de Doñana,

Consejo Superior de Investigaciones Científicas (CSIC),

Avda. Américo Vespucio s/n,

41092 Seville, Spain

e-mail: samer@ebd.csic.es

\section{J. M. Pérez}

Departamento de Biología Animal, Biología Vegetal y Ecología,

Universidad de Jaén,

Campus Las Lagunillas, s/n,

23071 Jaén, Spain conservation and management of the Western European ibex populations.

Keywords Capra ibex Capra pyrenaica . Goats .

OLADRB1 · MHC DRB1 · Linkage disequilibrium .

DRB-STR method

\section{Introduction}

In vertebrates, the major histocompatibility complex (MHC) plays a central role in foreign antigen recognition and immune response to pathogens and parasites (Klein 1986; Trowsdale 1993; Bernatchez and Landry 2003). High levels of allelic diversity have been found in MHC genes (Robinson et al. 2003) making these closely linked genes some of the most polymorphic regions in the vertebrate genome (Klein 1986). The mechanisms for maintaining this extraordinary polymorphism have been hotly debated among immunogeneticists and evolutionary biologists (Hedrick and Thompson 1983; Knapp 2007). Interestingly, populations of domesticated species have also been found to have high levels of MHC variation, higher than expected given the domestication history (Vilà et al. 2005). However, many endangered species exhibit low MHC polymorphisms, caused by their severe population bottlenecks (Hedrick 1999; Mainguy et al. 2007). Low MHC variability can also originate from the social organisation of a species (Ellegren et al. 1996; Sommer et al. 2002), which may result in low transmission rates of parasites and infectious diseases (Slade 1992; Murray et al. 1995).

MHC class II genes encode cell surface glycoproteins that present extracellular foreign peptides to $\mathrm{T}$ cell receptors to generate an adequate immune response (Doherty and Zinkernagel 1975). These genes are usually characterized 
by high levels of diversity among vertebrates (Garrigan and Hedrick 2003). Because of the high polymorphism of the MHC DRB region, routine typing is generally performed using different techniques, e.g., sequence specific oligonucleotide typing (Schwaiger et al. 1993), single strand conformational polymorphism (Kostia et al. 1998; Jugo and Vicario 2000), PCR followed by restriction fragment length polymorphism (Dutia et al. 1994; Amills et al. 1996), and 454 pyrosequencing (Babik et al. 2009). In addition, DRB cloning and subsequent sequencing often are inevitable (Nagaoka et al. 1999). These methods are powerful and have been successfully employed in several ruminant species. They are, however, laborious and/or expensive and more straightforward typing protocols are, therefore, desirable (de Groot et al. 2008).

A complex microsatellite repeat, designated DRB-STR, located in close proximity to DRB exon 2 is present in many mammalian species, including humans and primates (Andersson et al. 1987; Doxiadis et al. 2007). This microsatellite is located at the beginning of intron 2 and has a compound character (Trtkova et al. 1995; Bergstrom et al. 1999; Kriener et al. 2000). In humans and Rhesus macaques, genotyping of large samples resulted in the definition of DRB-STR patterns that were characteristic for a certain haplotype (Doxiadis et al. 2007). Associations between polymorphisms in an intronic microsatellite and the coding sequences for class II MHC genes were also reported in bovids (e.g., Sigurdardottir et al. 1991; Ellegren et al. 1993) and domestic and wild sheep (Schwaiger et al. 1993; Outteridge et al. 1996; Paterson 1998). To our knowledge, it has not yet been investigated whether similar patterns hold true in wild goats (genus Capra). Here we report a unique DRB-STR association in two wild Capra species, the Iberian (Capra pyrenaica) and Alpine ibex (Capra ibex).

Alpine and Iberian ibex share a similar history of overexploitation and severe bottlenecks. Less than 100 individuals of Alpine ibex (C. ibex) survived in the Gran Paradiso massif in northern Italy in the $1800 \mathrm{~s}$, after centuries of demographic decline mainly due to overexploitation (Couturier 1962a, b; Boitani et al. 2003). Current ibex populations found in the Alps are the result of translocations from this original source population and, to a much lesser extent, natural colonization. Reintroductions started at the beginning of the twentieth century in the Swiss Alps, while in Italy they mostly have been carried out in the last 20-30 years. Nonetheless, Alpine ibex are still absent from a significant portion of their potential distribution range, and its distribution is still scattered (Stüwe and Nievergelt 1991).

Similarly, parasite epidemics, uncontrolled hunting, and progressive destruction of natural habitats played an important role in the demographic decline of the Iberian ibex (C. pyrenaica), and the occurrence of severe population bottlenecks during the last two centuries is well documented (Pérez et al. 2002). Four subspecies of Iberian ibex were officially recognized (Cabrera 1911, 1914) but two of them (Capra pyrenaica pyrenaica and Capra pyrenaica lusitanica) went extinct recently. The persistent subspecies (Capra pyrenaica hispanica and Capra pyrenaica victoriae) have an allopatric distribution in the Iberian Peninsula (Manceau 1997). The aim of the present study was to develop a simple and relatively inexpensive protocol for Iberian and Alpine ibex MHC DRB1 gene genotyping based on OLADRB1 microsatellite analysis.

\section{Materials and methods}

\section{Samples collection and DNA extraction}

We collected 160 Iberian ibex samples from several Spanish populations, including both $C$. p. hispanica and $C$. $p$. victoriae, and 98 Alpine ibex from Switzerland and Italy in the years 2003-2008 (Table 1). Samples consisted of tissue or blood obtained from legally hunted, naturally deceased, or anesthetized animals and from collection with biopsy darts (Biebach and Keller 2009). Tissue samples were stored in $100 \%$ ethanol and blood samples in APS buffer at $-20^{\circ} \mathrm{C}$ before genomic DNA extraction with a commercial kit (BioSprint 96 and QIAamp DNA Mini Kit; QIAGEN).

OLADRB1 microsatellite genotyping

PCR (30-36 amplification cycles depending on DNA concentration) was conducted using $2 \mu \mathrm{L}$ DNA, OLADRB1

Table 1 The number of Iberian and Alpine ibex samples obtained from each country and geographical locality

\begin{tabular}{llll}
\hline Species & Country & Geographical locality & Samples number \\
\hline C. pyrenaica hispanica & Spain & Sierra Nevada Natural Space & 60 \\
C. pyrenaica hispanica & Spain & Maestrazgo and Parque Natural de los Puertos de Tortosa y Beceite & 72 \\
C. pyrenaica victoriae & Spain & Sierra de Gredos & 28 \\
C. ibex & Switzerland & Different geographical localities & 87 \\
C. ibex & Italy & Gran Paradiso & 11 \\
\hline
\end{tabular}


Table 2 DRB1 gene and associated OLADRB1 microsatellite alleles found in Iberian and Alpine ibex

\begin{tabular}{|c|c|c|c|c|c|}
\hline Capra species & Animal number & MHC DRB1 locus & MHC DRB1 locus frequency (\%) & OLADRB1 & OLADRB1 frequency $(\%)$ \\
\hline \multirow[t]{5}{*}{ C. p. hispanica } & \multirow[t]{5}{*}{592} & Capy-DRB $1 * 1$ & 27.60 & 169 & 27.60 \\
\hline & & Capy-DRB $1 * 2$ & 5.8 & 159 & 5.8 \\
\hline & & Capy-DRB1*3 & 33.57 & 187 & 33.57 \\
\hline & & Capy-DRB1*5 & 16.96 & 172 & 16.96 \\
\hline & & Capy-DRB $1 * 6$ & 16.07 & 185 & 16.07 \\
\hline \multirow[t]{4}{*}{ C. p. victoriae } & \multirow[t]{4}{*}{28} & Capy-DRB1*1 & 38 & 169 & 38 \\
\hline & & Capy-DRB1*2 & 48 & 159 & 48 \\
\hline & & Capy-DRB1*3 & 2 & 187 & 2 \\
\hline & & Capy-DRB1*6 & 12 & 187 & 12 \\
\hline \multirow[t]{2}{*}{ C. ibex } & \multirow[t]{2}{*}{98} & Caib-DRB1*1 & 86 & $170,174,178$ & 86 \\
\hline & & Caib-DRB1*2 & 14 & 184 & 14 \\
\hline
\end{tabular}

primers (Schwaiger et al. 1993; Paterson 1998), $0.25 \mu \mathrm{M}$ of each primer, and $1 \times$ Multiplex PCR Master Mix (QIAGEN) in a final volume of $5 \mu \mathrm{L}$. Using 96-well plates, aliquots of $20 \mu \mathrm{L}$ of formamide with LIZ size standard and $2 \mu \mathrm{L}$ of PCR product were analyzed on an ABI 3100 Avant automated sequencer. Allele sizes and genotypes were determined using GeneMapper 3.7 (Applied Biosystems) followed by manual proofreading.

\section{PCR amplification and sequencing of MHC DRB1 gene}

The second exon of the DRB1 gene was sequenced using seminested PCR as reported by Schaschl et al. (2004). The PCR reaction mixture for PCR I (preamplification) consisted of $2 \mu \mathrm{L}$ of gDNA, $0.25 \mu \mathrm{M}$ of each primer (using primer pairs HL030 and HL031 for C. ibex, Schaschl et al. (2004), and DRB1.1 and GIo for C. pyrenaica, Schwaiger et al. 1993), $0.217 \mu \mathrm{M}$ dNTP's, $1 \times$ buffer (QIAGEN), and $0.1 \mu \mathrm{L}$ Taq Polymerase $(5 \mathrm{U} / \mu \mathrm{L})$ in a final volume of $10 \mu \mathrm{L}$. Samples were subjected to the following thermal profile for amplification in a 2720 Thermal Cycler PTC-0200 DNA Engine Thermal Cycler (Bio-Rad) or a GeneAmp PCR
System 9700 (Applied Biosystems): 5 min at $94^{\circ} \mathrm{C}$ (initial denaturing), followed by 10 cycles of three steps of $1 \mathrm{~min}$ at $94^{\circ} \mathrm{C}$ (denaturation), $1 \mathrm{~min}$ at $60^{\circ} \mathrm{C}$ (annealing), and $90 \mathrm{~s}$ at $72^{\circ} \mathrm{C}$ (extension), before a final elongation of $5 \mathrm{~min}$ at $72^{\circ} \mathrm{C}$. PCR blanks (reagents only) were included. We used $2 \mu \mathrm{L}$ of the PCR product of PCR I as a template for PCR II (seminested), using primers HL030 and HL032 for C. ibex (Schaschl et al. 2004) and DRB1.1 and DRB1.2 for $C$. pyrenaica (Schwaiger et al. 1993), and the same PCR reaction mixture and thermal profile as in PCR I, with some modifications: the annealing temperature was modified to $65^{\circ} \mathrm{C}$, and the number of cycles was increased from 10 to 25 . PCR blanks (reagents only) were again included.

Sequencing reactions were carried out using the Big Dye ${ }^{\circledR}$ Terminator v1.1 cycle sequencing kit following the manufacturer's instructions (Applied Biosystems). Fragments were sequenced on an ABI 3100 Avant automated sequencer and DNA sequences were aligned and edited using the software BioEdit v.7.0.9 (Hall 1999). Alleles' inference from heterozygous sequences was carried out with the program PHASE (Stephens et al. 2001) for Iberian ibex, and by eye for Alpine ibex.

Table 3 Estimates of evolutionary divergence between Iberian and Alpine Ibex MHC-DRB1 alleles: the number of base substitutions per site from between sequences are shown

\begin{tabular}{llllllll}
\hline & Caib-DRB1*1 & Caib-DRB1*2 & Capy-DRB1*1 & Capy-DRB1*2 & Capy-DRB1*3 & Capy-DRB1*5 & Capy-DRB1*6 \\
\hline Caib-DRB1*1 & & 0.038 & 0.038 & 0.042 & 0.038 & 0.043 & 0.041 \\
Caib-DRB1*2 & 0.173 & & 0.008 & 0.048 & 0.034 & 0.042 & 0.036 \\
Capy-DRB1*1 & 0.173 & 0.013 & & 0.048 & 0.036 & 0.043 & 0.037 \\
Capy-DRB1*2 & 0.196 & 0.228 & 0.228 & & 0.029 & 0.036 & 0.019 \\
Capy-DRB1*3 & 0.173 & 0.152 & 0159 & 0.119 & & 0.031 \\
Capy-DRB1*5 & 0.204 & 0.196 & 0.204 & 0.159 & 0.067 & 0.083 \\
Capy-DRB1*6 & 0.188 & 0.159 & 0.166 & 0.132 & 0.013 & 0.083 \\
\hline
\end{tabular}

Standard error estimates are shown above the diagonal and were obtained by using analytical formulas. Analyses were conducted using the JukesCantor model. The rate variation among sites was modeled with a gamma distribution (shape parameter $=0.53$ ) 
Molecular analyses

Microsatellite null alleles were estimated using CERVUS v.3.0 (Marshall et al. 1998). The linkage between MHC and microsatellite was evaluated by eye. The most appropriate substitution models for the data were determined by the Akaike Information Criterion (Posada and Buckley 2004) in MEGA 5.04 (Tamura et al. 2011). Estimates of evolutionary divergence between sequences were performed with the same program.

\section{Results and discussion}

Sequencing the second exon of MHC DRB1 and genotyping the OLADRB1 microsatellite locus in $160 \mathrm{C}$. pyrenaica and 98 C. ibex detected a total of seven DRB1 exon II alleles: five in Iberian ibex: Capy-DRB1*1, Capy-DRB1*2, CapyDRB1*3, Capy-DRB1*5, and Capy-DRB1*6 (Amills et al. 2004) and two alleles in Alpine ibex: Caib-DRB1*1 (Schaschl et al. 2006) and Caib-DRB1*2 (Takada et al. 1998). Nine OLADRB1 microsatellite alleles were detected: five alleles in C. pyrenaica $(159,169,172,185$, and 187) and four alleles in C. ibex $(170,174,178$, and 184). No microsatellite null alleles were detected in this locus $(p<$ 0.05 ). These microsatellite alleles were unambiguously linked to the corresponding DRB1 exon II alleles: each DRB1 allele had one or several uniquely associated microsatellite alleles (Table 2). The large sample size used in our study together with the low number of alleles detected allowed us to easily infer gametic association in the case of double heterozygotes, based on the data of the homozygote individuals. Thus, OLADRB1 genotyping provides an accurate and simple MHC DRB1 genotyping matching method for Iberian and Alpine ibex. Interestingly, while we found a 1:1 microsatellite to DRB1 sequence match in most cases, one DRB1 exon II allele in Alpine ibex was associated with three different microsatellite alleles (Table 2). The strong linkage we observed is probably a consequence of the close proximity of the OLADRB1 microsatellite to the DRB1 gene. In sheep, OLADRB1 is located in an intron about $30 \mathrm{bp}$ $3^{\prime}$ to the second exon of the DRB1 gene (Schwaiger et al. 1993). It appears that a similar situation occurs in the Capra species studied here.

The best-fitting evolutionary model, inferred from the seven DRB1 gene alleles, was JC (Jukes Cantor model; Jukes and Cantor 1969) $+\mathrm{G}$ (shape parameter, $\alpha=0.53,-\ln L=-731.164$ ). The evolutionary divergence among all DRB gene alleles, based on the selected model, ranged from $1.3 \%$ (between Caib-DRB1*2 and Capy-DRB1*1) to $22.8 \%$ (between CapyDRB $1 * 1$ and Capy-DRB1*2; and between Caib-DRB $1 * 2$ and Capy-DRB1*2) (Table 3). The two Alpine ibex alleles differed by $17.3 \%$, while the intra-Iberian ibex evolutionary divergence was $13.3 \%$. The inter-ibex species distance (between $C$. ibex and $C$. pyrenaica) was $16.8 \%$. Hence intra-Alpine ibex genetic diversity was bigger than that for Iberian ibex and even bigger than the inter-ibex species genetic distance (Table 3).

In this study we used a large sampling size (258 ibex) including both existing subspecies of Iberian ibex (C. $p$. hispanica and $C$. p. victoriae) throughout its distribution range in Spain, together with representative sampling from Italian and Swiss Alpine ibex, including samples from the Gran Paradiso massif (the source of all existing Alpine ibex populations). The large sample size together with the low number of DRB1 gene alleles supports the applicability of our method to the unstudied ibex populations.

The small size differences among OLADRB1 alleles (in some cases only $1 \mathrm{bp}$ was detected between microsatellite alleles from both ibex species: e.g., 169 allele linked to CapyDRB1*1 from $C$. pyrenaica and 170 allele linked to CaibDRB1*1 from $C$. ibex) require the use of positive controls when performing PCR amplifications, to overcome the possible lack of consistency in allele sizes. This is particularly important if different sequencers and running conditions are used in different laboratories (Pasqualotto et al. 2007).

Our new DRB-STR panel in two Capra species provides an indirect method for MHC haplotyping without the need for multiple post-PCR manipulations of samples in cloning, sequencing reactions, and/or restriction digests. These manipulations add time and cost to sample processing and increase the possibility of human error and/or contamination. Our DRB-STR panel is particularly helpful when a large number of samples are to be analyzed, as for example in population and/or disease association studies.

Acknowledgments We thank Helmut Schaschl for the valuable discussions about MHC in ungulates, Thomas Bucher for assistance in genotyping, Peter Wandeler for the help with troubleshooting in the lab, and Achaz von Hardenberg and Bruno Bassano for providing samples from Italy. We also acknowledge Daniel Fernéndez de Luco (Universidad de Zaragoza), Santiago Lavín (Universidad Autónoma de Barcelona), Miguel Ángel Habela (Universidad de Extremadura), and José E. Granados (Espacio Natural de Sierra Nevada) for sample collection. This project was funded by the Swiss Federal Office for the Environment and the Forschungskredit of the University of Zurich (Switzerland), and the programme 'Ayudas a Grupos de Investigación' to RNM118 investigation group (Andalucía, Spain).

\section{References}

Amills M, Francino O, Sànchez A (1996) A PCR-RFLP typing method for the caprine Mhc class II DRB gene. Vet Immunol Immunopathol 55:255-260

Amills $\mathrm{M}$, Jiménez $\mathrm{N}$, Jordana $\mathrm{J}$, Riccardi $\mathrm{A}$, Fernàndez-Arias $\mathrm{A}$, Guiral J, Bouzat JL, Folch J, Sànchez A (2004) Low diversity in the major histocompatibility complex class II DRB1 gene of the Spanish ibex, Capra pyrenaica. Heredity 93:266-272 
Andersson G, Larhammar D, Widmark E, Servenius B, Peterson PA, Rask L (1987) Class II genes of the human major histocompatibility complex. Organization and evolutionary relationship of the DR beta genes. J Biol Chem 262:8748-8758

Babik W, Taberlet P, Ejsmond MJ, Radwan J (2009) New generation sequencers as a tool for genotyping of highly polymorphic multilocus MHC system. Mol Ecol Resour 9:713-719

Bergstrom TF, Engkvist H, Erlandsson R, Josefsson A, Mack SJ, Erlich HA, Gyllensten U (1999) Tracing the origin of HLADRB1 alleles by microsatellite polymorphism. Am J Hum Genet 64:1709-1718

Bernatchez L, Landry C (2003) MHC studies in nonmodel vertebrates: what have we learned about natural selection in 15 years? J Evol Biol 16:363-377

Biebach I, Keller LF (2009) A strong genetic footprint of the reintroduction history of Alpine ibex (Capra ibex ibex). Mol Ecol 18:5046-5058

Botani L, Lovari S, Vigna-Taglianti A (2003) Fauna d'Italia. Mammalia III: carnivora - artiodactyla. Edizioni Calderini, Bologna. pp 434

Cabrera A (1911) The subspecies of Spanish ibex. Proc Zool Soc London 1911:963-967

Cabrera A (1914) Fauna ibérica; mamíferos. Museo Nacional de Ciencias Naturales, Madrid

Couturier, M., (1962) Le bouquetin des Alpes (Capra aegagrus ibex ibex L.). (edited by the author). Grenoble. pp 1564

Couturier MAJ (1962b) Le Bouquetin des Alpes. Allier, Grenoble, p 1564

de Groot N, Doxiadis GG, de Vos-Rouweler AJ, de Groot NG, Verschoor EJ, Bontrop RE (2008) Comparative genetics of a highly divergent DRB microsatellite in different macaque species. Immunogenetics 60:737-748

Doherty PC, Zinkernagel RM (1975) A biological role for major histocompatibility antigens. Lancet 1:1406-1409

Doxiadis GG, de Groot N, Claas FHJ, Doxiadis IIN, van Rood JJ, Bontrop RE, (2007) A highly divergent microsatellite facilitating fast and accurate DRB haplotyping in humans and rhesus macaques. Proc Natl Acad Sci U S A, 104:8907-8912

Dutia BM, McConnell I, Ballingall KT, Keating P, Hopkins J (1994) Evidence for the expression of two distinct MHC class II DR beta like molecules in the sheep. Anim Genet 25:235-241

Ellegren H, Davies CJ, Andersson L (1993) Strong association between polymorphisms in an intronic microsatellite and in the coding sequence of the BoLA-DRB3 gene: implications for microsatellite stability and PCR-based typing. Anim Genet 24:269-275

Ellegren H, Mikko S, Wallin K, Andersson L (1996) Limited polymorphism at major histocompatibility complex (MHC) loci in the Swedish moose A. alces. Mol Ecol 5:3-9

Garrigan D, Hedrick PW (2003) Perspective: detecting adaptive molecular polymorphism: lessons from the MHC. Evolution 57:1707-1722

Hall TA (1999) BioEdit: a user-friendly biological sequence alignment editor and analysis program for Windows 95/98/NT. Nucleic Acids Symp 41:95-98

Hedrick PW (1999) Perspective: highly variable loci and their interpretation in evolution and conservation. Evolution 53:313-318

Hedrick PW, Thompson G (1983) Evidence for balancing selection at HLA. Genetics 104:449-456

Jugo BM, Vicario A (2000) Single-strand conformational polymorphism and sequence polymorphism of MHC-DRB in Latxa and Karrantzar sheep: implications for Caprinae phylogeny. Immunogenetics 51:887-897

Jukes TH, Cantor CR (1969) Evolution of protein molecules. In: Munro HN (ed) Mammalian protein metabolism. Academic Press, New York, pp 21-132

Klein J (1986) The natural history of the major histocompatibility complex. Wiley, New York
Knapp LA (2007) Selection on MHC: a matter of form over function. Heredity 99:241-242

Kostia S, Kantanen J, Kolkkala M, Varvio SL (1998) Applicability of SSCP analysis for MHC genotyping: fingerprinting of OvarDRB1 exon 2 alleles from Finnish and Russian breeds. Anim Genet 29:453-455

Kriener K, O'Huigin C, Tichy H, Klein J (2000) Convergent evolution of major histocompatibility complex molecules in humans and new world monkeys. Immunogenetics 51:169-178

Mainguy J, Worley K, Côté SD, Coltman DW (2007) Low MHC DRB class II diversity in the mountain goat: past bottlenecks and possible role of pathogens and parasites. Conserv Genet $8: 885-891$

Manceau V (1997) Polymorphisme des séquences d'ADN mitochondrial dans le genre Capra. Application à la conservation du bouquetin des Pyrénées $(C$. pyrenaica pyrenaica). Dissertation, University Joseph Fourier

Marshall TC, Slate J, Kruuk L, Pemberton JM (1998) Statistical confidence for likelihood-based paternity inference in natural populations. Mol Ecol 7:639-655

Murray BW, Malik S, White BN (1995) Sequence variation at the major histocompatibility complex locus $\mathrm{DQ} \beta$ in Beluga whales (Delphinapterus leucas). Mol Biol Evol 12:582-593

Nagaoka Y, Kabeya H, Onuma M, Kasai N, Okada K, Aida Y (1999) Ovine MHC class II DRB1 alleles associated with resistance or susceptibility to development of bovine leukemia virus-induced ovine lymphoma. Cancer Res 59:975-981

Outteridge PM, Andersson L, Douch PGC, Green RS, Gwakisa PS, Hohenhaus MA, Mikko S (1996) The PCR typing of MHC-DRB genes in the sheep using primers for an intronic microsatellite: application to nematode parasite resistance. Immunol Cell Biol 74:330-336

Pasqualotto AC, Denning DW, Anderson MJ (2007) A cautionary tale: lack of consistency in allele sizes between two laboratories for a published multilocus microsatellite typing system. J Clin Microbiol 45:522-528

Paterson S (1998) Evidence for balancing selection at the major histocompatibility complex in a free-living ruminant. J Hered 89:289-294

Pérez JM, Granados JE, Soriguer RC, Fandos P, Márquez FJ, Crampe JP (2002) Distribution, status and conservation problems of the Spanish ibex, Capra pyrenaica (Mammalia: Artiodactyla). Mammal Rev 32:26-39

Posada D, Buckley TR (2004) Model selection and model averaging in phylogenetics: advantages of the aic and bayesian approaches over likelihood ratio tests. Syst Biol 53:793-808

Robinson J, Waller MJ, Parham P, de Groot N, Bontrop R, Kennedy LJ, Stoehr P, Marsh SGE (2003) IMGT/HLA and IMGT/MHC: sequence databases for the study of the major histocompatibility complex. Nucleic Acids Res 31:311-314

Schaschl H, Goodman SJ, Suchentrunk F (2004) Sequence analysis of the MHC class II DRB alleles in Alpine chamois (Rupicapra $r$. rupicapra). Dev Comp Immunol 28:265-277

Schaschl H, Wandeler P, Suchentrunk F, Obexer-Ruff G, Goodman SJ (2006) Selection and recombination drive the evolution of MHC class II DRB diversity in ungulates. Heredity 97:427-437

Schwaiger FW, Buitkamp J, Weyers E, Epplen JT (1993) Typing of Artiodactyl MHC-DRB genes with the help of intronic simple repeated DRD-sequences. Mol Ecol 2:55-59

Sigurdardottir S, Borsch C, Gustaffson K, Andersson L (1991) Cloning and sequence analysis of 14 DRB alleles of the bovine major histocompatibility complex by using the polymerase chain reaction. Anim Genet 22:199-209

Slade RW (1992) Limited MHC polymorphism in the Southern elephant seal: implication for MHC evolution and marine mammal population biology. Proc Biol Sci 249:163-171 
Sommer S, Schwab D, Ganzhorn JU (2002) MHC diversity of endemic Malagasy rodents in relation to geographic range and social system. Behav Ecol Sociobiol 51:214-221

Stephens M, Smith NJ, Donnelly P (2001) A new statistical method for haplotype reconstruction from population data. Am J Hum Genet 68:978-989

Stüwe MB, Nievergelt B (1991) Recovery of Alpine ibex from near extinction: the result of effective protection, captive breeding, and re-introductions. Appl Anim Behav Sci 29:379-387

Takada T, Kikkawa Y, Yonekawa H, Amano T (1998) Analysis of goat MHC class II DRA and DRB genes: identification of the expressed gene and new DRB alleles. Immunogenetics 48:408-412
Tamura K, Peterson D, Peterson N, Stecher G, Nei M, Kumar S (2011) MEGA5: molecular evolutionary genetics analysis using maximum likelihood, evolutionary distance, and maximum parsimony methods. Mol Biol Evol 24:1596-1599

Trowsdale J (1993) Genomic structure and function in the MHC. Trends Genet 9:117-122

Trtkova K, Mayer WE, O’Huigin C, Klein J (1995) Mhc-DRB genes and the origin of New World monkeys. Mol Phylogenet Evol 4:408-419

Vilà C, Seddon J, Ellegren H (2005) Genes of domestic mammals augmented by backcrossing with wild ancestors. Trends Genet $21: 214-218$ 